\title{
Polarographic Analysis of Quetiapine in Pharmaceuticals
}

\author{
Nahed El-Enany, Amina El-Brashy, Fathalla Belal, Nihal El-Bahay \\ Faculty of Pharmacy, Department of Pharmaceutical Analytical Chemistry, University of \\ Mansoura, Mansoura, 35516, Egypt
}

Received 18 September 2008; accepted 11 February 2009

\begin{abstract}
The voltammetric behaviour of quetiapine (QTP) was studied using direct current $\left(\mathrm{DC}_{\mathrm{t}}\right)$, differential pulse (DPP) and alternating current $\left(\mathrm{AC}_{\mathrm{t}}\right)$ polarography. The drug manifests cathodic waves over the $\mathrm{pH}$ range of $6-11.8$. The waves were characterized as being irreversible, diffusion-controlled with limited adsorption properties. At $\mathrm{pH} 8$, the diffusion current-concentration relationship was rectilinear over the range of $8-44$ $\mu \mathrm{g} / \mathrm{mL}$ and $4-44 \mu \mathrm{g} / \mathrm{mL}$ using $\mathrm{DC}_{\mathrm{t}}$ and DPP modes, respectively, with minimum detection limits (LOD) of $0.06 \mu \mathrm{g} / \mathrm{mL}$ and $0.04 \mu \mathrm{g} / \mathrm{mL}$ using the $\mathrm{DC}_{\mathrm{t}}$ and DPP modes, respectively. The diffusion-current constant $\left(I_{d}\right)$ is $1.36 \pm 0.04(n=10)$. The proposed method was successfully applied to the determination of the studied compound both in pure form and in formulations. The results obtained were favourably compared with those obtained using a reference method. A pathway for the electrode reaction was postulated.
\end{abstract}

Keywords: quetiapine, dosage form, polarography.

\section{Introduction}

Quetiapine [QTP], 2-(2-(4-dibenzo [b,f][1,4] thiazepine- 11-yl-1-piperaminyl) ethoxy) ethanol (Fig. 1) belongs to a series of neuroleptics known as "a typical antipsychotic", which have, over the last four decades, become increasingly popular alternatives to " typical antipsychotics", such as haloperidol. It is used for the treatment of schizophrenia, acute maniac bipolar disorder. Recently, it was approved by the FDA for the treatment of depressive episodes associated with Bipolar I (or Bipolar-II) disorder as a single agent monotherapy. It is also used to treat other disorders, such as post-traumatic stress disorder, alcoholism, obsessive compulsive disorder, anxiety disorders, hallucinations in Parkinson's

\footnotetext{
* Corresponding author. E-mail address: nelenany1@yahoo.com
} 
disease patients using ropinirole, and as a sedative for those with sleep disorders [1].

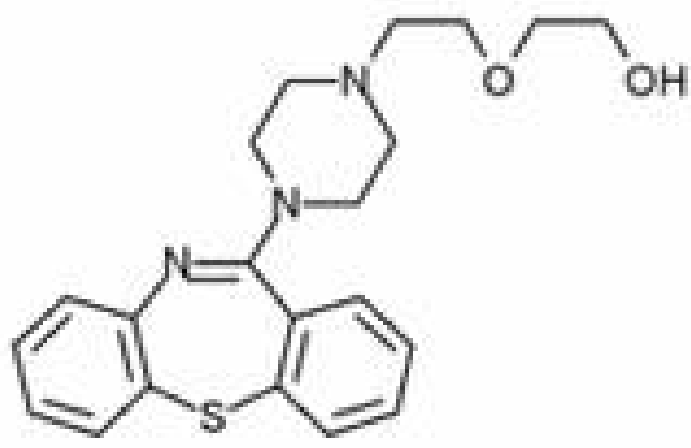

Figure 1. Structural formula of quetiapine.

Various methods have been reported for the estimation of QTP either per se or in pharmaceutical preparations and biological fluids viz spectrophotometry [2], GC [3], HPLC [4-13] and capillary electrophoresis [14-15].

Although chromatographic methods offer high degree of specificity, yet, sample clean up and the instrument limitations preclude their use in routine clinical studies. Voltammetric technique offers another possibility for the estimation of this compound. Review of the literature revealed that, up to the present time, nothing has been reported concerning the polarographic behaviour of quetiapine. The molecular structure of the studied compound is characterized by the presence of an electroactive reducible azomethane group; this fact initiated the present study.

\section{Experimental}

\section{Apparatus}

The polarographic study and DPP measurements were carried out using the polarecord E 506 Metrohm (Herisau, Switzerland). The drop time of $1 \mathrm{~s}$ was electronically controlled using a 663 VA Stand from the company. The polarograms were recorded using a potential scan rate of $10 \mathrm{mV} \mathrm{s}$. A three electrode system composed of a dropping mercury electrode (DME), $\mathrm{Ag} / \mathrm{AgCl}$ reference electrode, and a graphite rod as the auxiliary electrode, was used. Phase selective $A_{t}$ polarograms were recorded using the same instrument, the superimposed alternating voltage being $15 \mathrm{mV}$ at a frequency of $75 \mathrm{~Hz}$ and a phase angle of $90^{\circ}$. The effect of mercury height was studied using a $506 \mathrm{VA}$ Stand of the same company with a $\mathrm{Ag} / \mathrm{AgCl}$ reference electrode and a platinum wire as an auxiliary electrode. The solutions were purged with pure nitrogen gas for $5 \mathrm{~min}$, then polarographed at room temperature.

\section{Materials and reagents}

All reagents were analytical grade. 


\section{Materials}

QTP pure drug sample was kindly provided by UK Astrazeneca Company. Seroquel tablets (labelled to contain $300 \mathrm{mg}$ QTP per tablet, batch \# 10081) were obtained from UK Zeneca Company.

\section{Reagents}

Britton Robinson buffers $(\mathrm{BRb})(0.08 \mathrm{M})$ [16] covering the working $\mathrm{pH}$ range 6.0 - 11.8. Methanol: AR grade (Aldrich-Chemie, Germany). BRb buffers were prepared as follows: the acidic part by mixing $0.04 \mathrm{M}$ boric acid with $0.04 \mathrm{M}$ acetic acid and $0.04 \mathrm{M}$ phosphoric acid; the basic part was formed of $0.4 \mathrm{M}$ $\mathrm{NaOH}$. Appropriate volumes of the basic part were mixed with the acidic part to obtain the desired $\mathrm{pH}$.

A stock solution containing $200 \mu \mathrm{g} / \mathrm{mL}$ of QTP was prepared in methanol and was further diluted with the same solvent to give the appropriate concentrations.

\section{Procedure}

\section{General analytical procedure}

Aliquot volumes of the stock solution were transferred into a series of $25-\mathrm{mL}$ volumetric flasks so that the final concentration is in the range of $8-44$ and $4-$ $44 \mu \mathrm{g} \cdot \mathrm{mL}^{-1}$ for the $\mathrm{DC}_{\mathrm{t}}$ and DPP modes, respectively. The volumes were completed to the mark with $\mathrm{BRb}$ of $\mathrm{pH}$ 8.0. The whole content of the flask was transferred into the polarographic cell, nitrogen gas was passed for $5 \mathrm{~min}$, then the polarograms were recorded in the $\mathrm{DC}_{\mathrm{t}}$ and $\mathrm{DP}$ polarographic modes over the potential range -0.4 to $-1.2 \mathrm{~V}$ versus $\mathrm{Ag} / \mathrm{AgCl}$. The current $(\mu \mathrm{A})$ was plotted versus the concentration $\left(\mu \mathrm{g} \cdot \mathrm{mL}^{-1}\right)$ to get the calibration graph. Alternatively, the corresponding regression equation was derived.

\section{Analysis of tablets}

For the analysis of pharmaceutical formulations 10 tablets were weighed and pulverized. A weighed quantity of the powdered tablets equivalent to $20.0 \mathrm{mg}$ of QTP was transferred into a small conical flask. Extracted three times each with $30 \mathrm{~mL}$ of methanol; the extracts were filtered through Whatman filter paper into a $100 \mathrm{~mL}$ volumetric flask. The conical flask was washed with few $\mathrm{mL}$ of methanol and the washings were passed into the volumetric flask and completed to the mark with methanol. From this solution aliquot volumes covering the working concentration range were transferred into $25-\mathrm{mL}$ volumetric flasks, completed as described under "General procedure". The nominal content of the tablets was determined either from the calibration graph or using the corresponding regression equation.

\section{Results}

\section{Electrochemical behavior of the studied compound}

The chemical structure of QTP is characterized by the presence of azomethine group which is susceptible for the reduction at DME such as cinolazepam [17] . 
Fig. 2 shows the typical ( $\mathrm{DC}_{\mathrm{t}}$ and $\mathrm{DPP}$ ) polarograms of QTP in $\mathrm{BRb}$ of $\mathrm{pH} 8.0$ containing $20 \%$ methanol. Methanol was added as a solvent for QTP; it also decreased the adsorption phenomena likely to occur at the surface of DME.

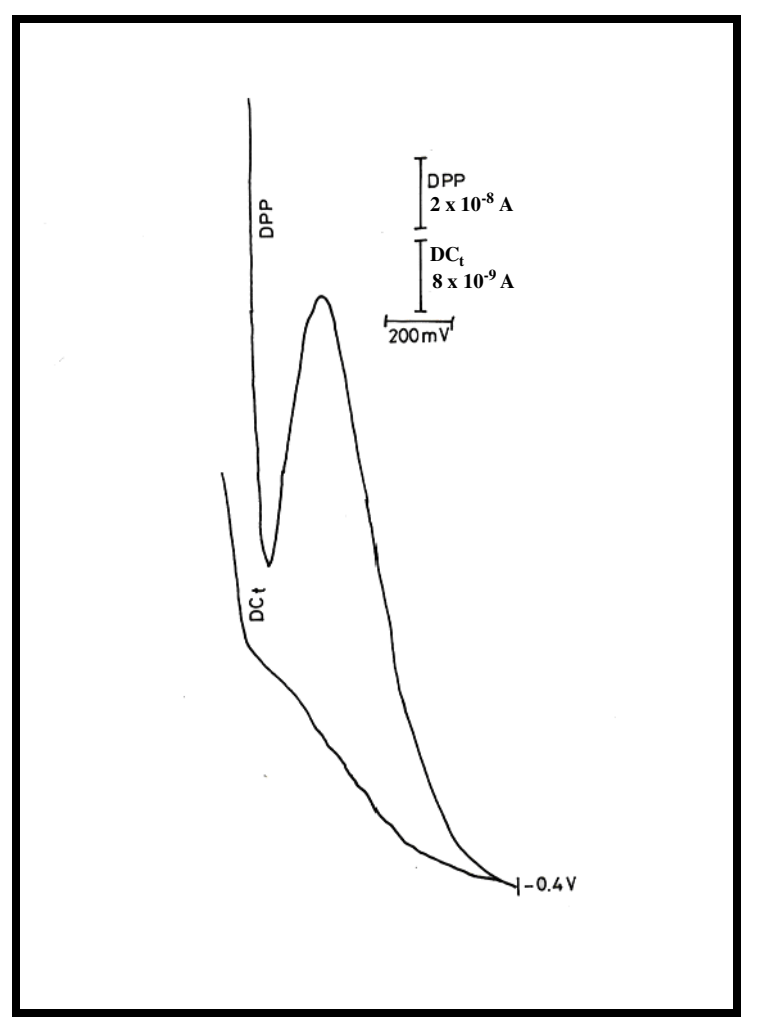

Figure 2. Typical polarogram of quetiapine $\left(20 \mu \mathrm{g} \cdot \mathrm{mL}^{-1}\right)$ in $\mathrm{BRb}$ at $\mathrm{pH} 8.0$.

\section{Optimization of the proposed analytical procedure}

Quetiapine produces a well-defined cathodic wave over the $\mathrm{pH}$ range of $7-11.8$ in BRb (Fig. 3). Reduction of QTP at the dropping mercury electrode was found to be $\mathrm{pH}$ dependent as the $\mathrm{E}^{1 / 2}$ values were shifted to more negative values upon increasing the $\mathrm{pH}$ (Fig. 3).

A plot of $\mathrm{E}^{1 / 2}$ versus $\mathrm{pH}$ gave two straight lines with one break at $\mathrm{pH} 6.8$ (Fig. 4) which corresponds to the second pKa of QTP [18].

The number of protons, $\mathrm{Z}$, consumed in the electrode reaction was calculated using the following equation [19]:

$$
\Delta \mathrm{E}_{1 / 2} / \Delta \mathrm{pH}=-0.059 \mathrm{Z} / \alpha \mathrm{n}_{\mathrm{a}}
$$

where $\alpha$ is the transfer coefficient. Values of $\alpha n_{a}$ were calculated from the following equation [20]:

$$
E=E^{1 / 2}-\left(0.059 / \alpha n_{a}\right) \log [(i / i d-i)]
$$


where id is the diffusion current. At $\mathrm{pH} 8.0, \mathrm{Z}$ was found to be 0.5 , i.e, one proton is probably consumed in the electrode reaction at the rate-determining step; this small value of $\mathrm{Z}$ indicates that the reaction is irreversible in nature.

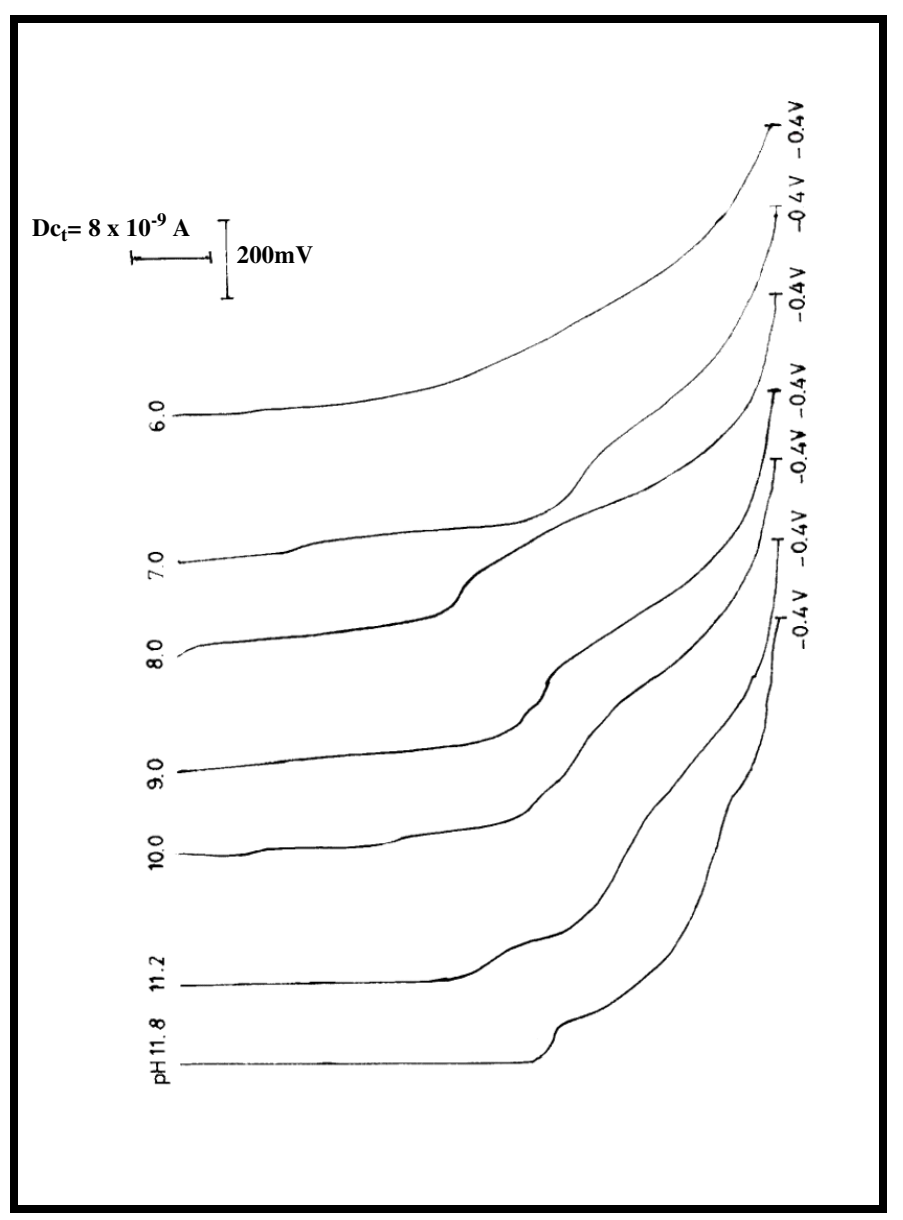

Figure 3. Effect of $\mathrm{pH}$ on the development of the polarographic waves of quetiapine (20 $\left.\mu \mathrm{g} \cdot \mathrm{mL}^{-1}\right)$ in $\mathrm{BRb}$.

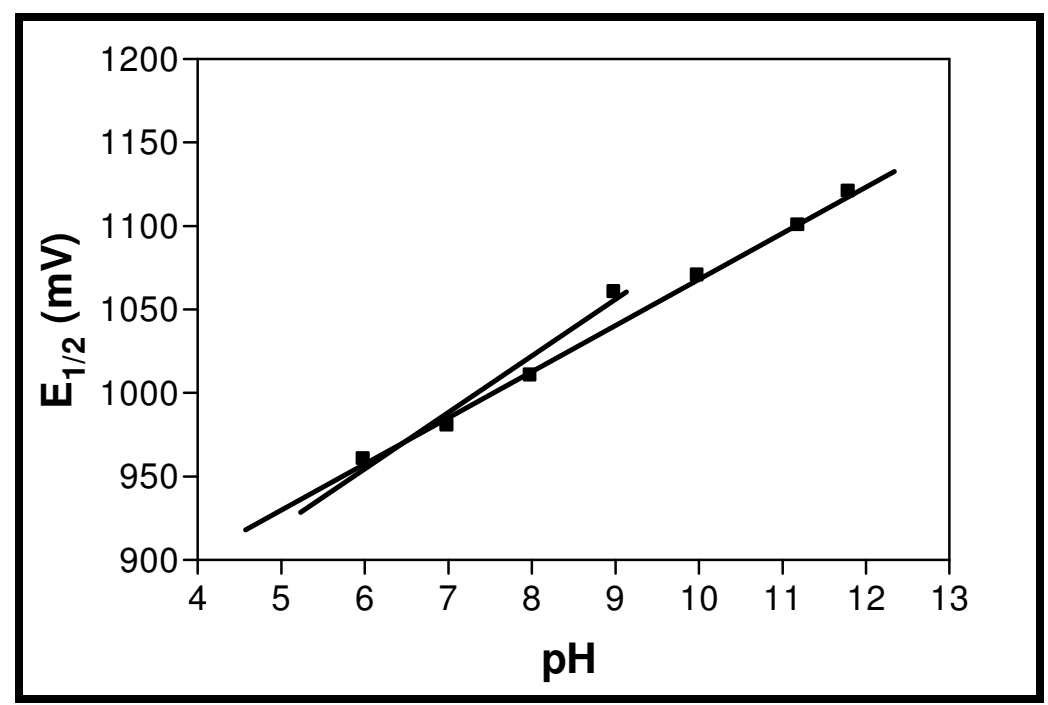

Figure 4. Effect of $\mathrm{pH}$ on the $\mathrm{E}_{1 / 2}(\mathrm{mV})$ values of quetiapine in $\mathrm{BRb}$. 
Logarithmic analysis of the reduction waves obtained in $\mathrm{BRb}$ of different $\mathrm{pH}$ values resulted in straight lines. $\alpha \mathrm{n}_{\mathrm{a}}$ values were calculated according to the treatment of Meites and Israel [20] and are listed in Table 1. At pH 8, $\alpha \mathrm{n}_{\mathrm{a}}$ was found to be 0.59. Assuming that the rate-determining step involves the transfer of two electrons, the value of $\alpha \mathrm{n}_{\mathrm{a}}$ points out to the completely irreversible nature of the reduction process.

Table 1. Effect of $\mathrm{pH}$ on the development of the polarographic waves of quetiapine.

\begin{tabular}{|c|c|c|c|c|c|c|}
\hline pH & $\Delta \mathbf{p H}$ & $\mathrm{E}_{1 / 2}(\mathrm{mV})$ & $\Delta \mathrm{E}_{1 / 2}(\mathrm{mV})$ & $\mathrm{W}_{1 / 2}(\mathrm{mV})$ & $\alpha \mathbf{n}_{\mathrm{a}}$ & $\mathbf{Z}$ \\
\hline 6 & & -960 & & 180 & 0.59 & 0.20 \\
\hline 7 & 1 & -980 & 20 & 220 & 0.62 & 0.32 \\
\hline 8 & 1 & -1010 & 30 & 200 & 0.59 & 0.50 \\
\hline 9 & 1 & -1060 & 50 & 200 & 0.51 & 0.08 \\
\hline 10 & 1 & -1070 & 10 & 260 & 0.45 & 0.19 \\
\hline 11.2 & 1.2 & -1100 & 30 & 260 & 0.43 & 0.24 \\
\hline 11.8 & 0.6 & -1120 & 20 & 120 & 0.49 & \\
\hline
\end{tabular}

$\mathbf{W}_{\mathbf{1} / \mathbf{2}}$ : half peak width in the DPP mode. $\boldsymbol{\alpha} \mathbf{n}_{\mathbf{a}}$ : number of electrons transferred at the rate determining step. $\mathbf{Z}$ : number of protons transferred. $\mathbf{E}_{\mathbf{1 / 2}}$ : the half wave potential in te $\mathrm{DC}_{\mathrm{t}}$ mode.

Changing the buffer concentration over the range $8 \times 10^{-3} \mathrm{M}$ to $7.2 \times 10^{-2} \mathrm{M}$ was found to yield a negligible effect on the wave heights of QTP. This indicates a diffusion-controlled wave, partially affected by adsorption phenomenon.

The alternating current behavior $\left(\mathrm{AC}_{\mathrm{t}}\right)$ of QTP was studied in $\mathrm{BRb}$ of different $\mathrm{pH}$ values $\left(6.0,7.0\right.$ and 8.0) at phase angle of $90^{\circ}$. In $\mathrm{BRb}$, the summit potentials $\left(E_{s}\right)$ were shifted to more negative values of 320,340 and $350 \mathrm{mV}$ more than the corresponding $\mathrm{E}^{1 / 2}$ value for $\mathrm{pH}$ values of 6,7 and 8 , respectively. Fig. 5 demonstrates that at $\mathrm{pH} 6.0$ and 7.0, adsorption of both depolarizer and its reduction product takes place to the surface of mercury, while at $\mathrm{pH} 8.0$ adsorption of only the depolarizer takes place (Fig. 5). From these studies, it is concluded that the produced polarographic waves are diffusion-controlled and partially affected by adsorption phenomenon.

Quetiapine was found to be stable in $\mathrm{BRb}$ of $\mathrm{pH} 8.0$ (the analytical $\mathrm{pH}$ ) for about one and half an hour at room temperature, after which its stability began to decrease slowly.

The diffusion current constant $\left(\mathrm{Id}=\mathrm{id} / \mathrm{Cm}^{2 / 3} \mathrm{t}^{1 / 6}\right)$ was calculated according to Ilkovic equation [21] for varying concentrations of the drug and was found to be $1.36 \pm 0.04(n=5)$. The diffusion coefficient $(\mathrm{D})$ of QTP was also calculated and was found to be $1.25 \times 10^{-6} \mathrm{~cm}^{2} \mathrm{~s}^{-1}$. This small value may be attributed to the bulky nature of the depolarizer. The results are shown in Table 2. 


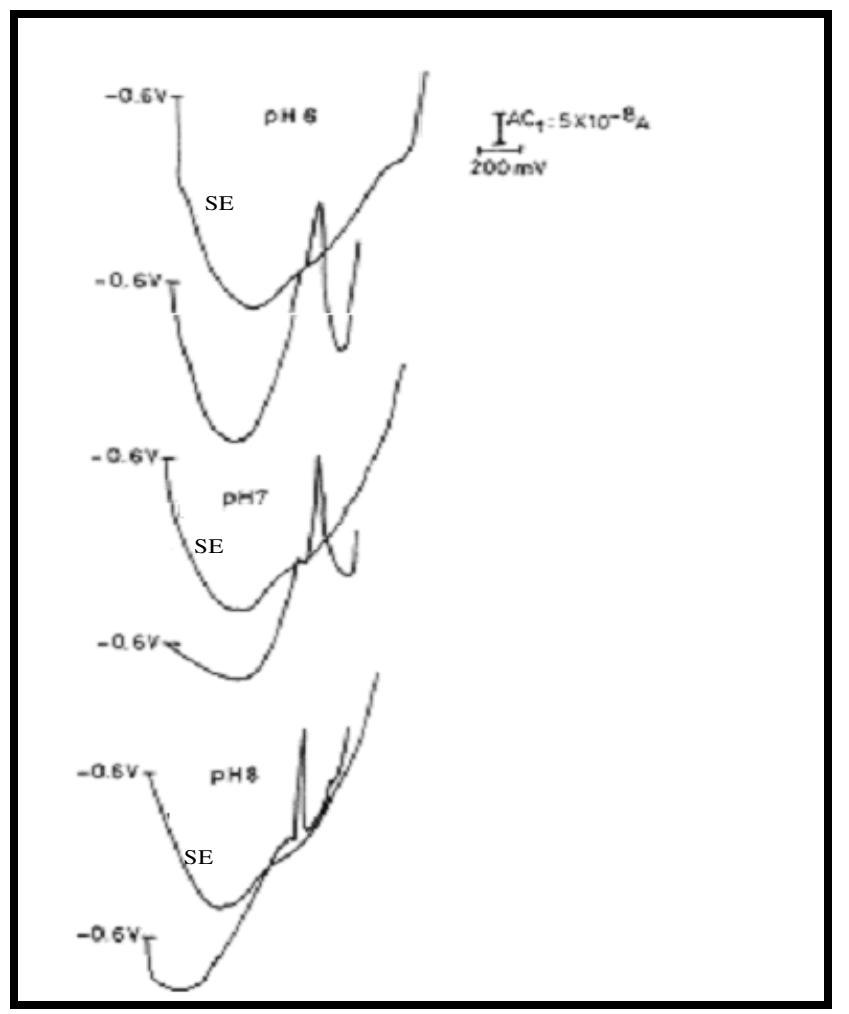

Figure 5. Alternating current behaviour of quetiapine $\left(20 \mu \mathrm{g} \cdot \mathrm{mL}^{-1}\right)$ in $\mathrm{BRb}$ of $\mathrm{pH}$ 8.0. Superimposed alternating voltage: $15 \mathrm{mV}$; frequency $75 \mathrm{~Hz}$; phase angle $90^{\circ}$. (SE: supporting electrolyte).

Table 2. Correlation between concentration of quetiapine and the diffusion current in the $\mathrm{DC}_{\mathrm{t}}$ mode.

\begin{tabular}{|c|c|c|c|}
\hline Conc. $(\mathbf{m M})$ & Current $(\boldsymbol{\mu} \mathbf{A})$ & id/C & Id \\
\hline & & & \\
0.020 & 0.034 & 1.62 & 1.34 \\
0.031 & 0.053 & 1.71 & 1.41 \\
0.042 & 0.067 & 1.60 & 1.32 \\
0.052 & 0.090 & 1.73 & 1.43 \\
0.063 & 0.102 & 1.62 & 1.34 \\
0.073 & 0.119 & 1.63 & 1.35 \\
0.084 & 0.137 & 1.63 & 1.35 \\
0.094 & 0.151 & 1.61 & 1.33 \\
0.104 & 0.170 & 1.63 & 1.35 \\
0.115 & 0.186 & 1.62 & 1.34 \\
& & 1.64 & 1.36 \\
Mean & & 0.043 & 0.035 \\
SD & &
\end{tabular}

The electrode reaction and the number of electrons transferred were determined through a comparative experimental study of the wave height of QTP with that obtained from an equimolar solution of a previously studied, structurally related compound with the same reducible azomethane group, and of nearly identical 
value of diffusion coefficient, namely benzydamine [22]. In BRb of $\mathrm{pH} 8.0$ both compounds gave one wave of the same height. Based on the presence of an active azomethane group and by analogy to previous study [22], the following mechanism is postulated:

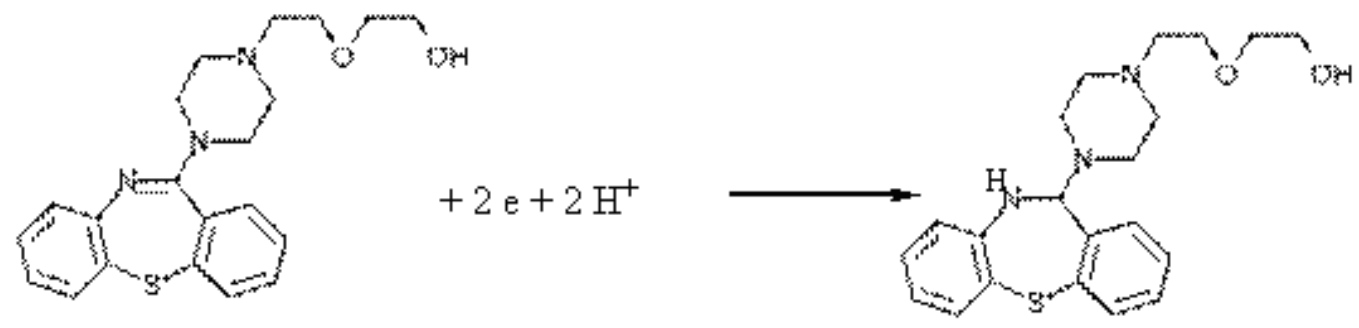

Scheme 1

\section{Calibration curve}

The proposed method was tested for linearity, sensitivity, accuracy and precision.

Under the described conditions at $\mathrm{pH}$ 8.0, polarogram of QTP exhibits a well defined diffusion controlled cathodic wave and steep differential pulse peak, both being suitable for analytical applications. No polarographic maximum was developed; hence no maximum suppressor was needed.

Current concentration plots were rectilinear over the concentration ranges of $8-$ 44 and $4-44 \mu \mathrm{g} \cdot \mathrm{mL}^{-1}$ using $\mathrm{DC}_{\mathrm{t}}$ and DPP modes, respectively, with minimum limits of detection (LOD) of 0.06 and $0.04 \mu \mathrm{g} \cdot \mathrm{mL}^{-1}$ using $\mathrm{DC}_{t}$ and DPP modes, respectively (Table 3 ).

Table 3. Performance data of the proposed method of quetiapine in the $\mathrm{DC}_{\mathrm{t}}$ and $\mathrm{DPP}$ modes.

\begin{tabular}{|l|c|c|}
\hline \multicolumn{1}{|c|}{ Parameter } & DC $_{\mathbf{t}}$ mode & DPP mode \\
\hline Concentration range $\left(\mu \mathrm{g} \cdot \mathrm{mL}^{-1}\right)$ & $8-44$ & $4-44$ \\
Limit of detection $\left(\mu \mathrm{g} \cdot \mathrm{mL}^{-1}\right)$ & 0.06 & 0.04 \\
Limit of quantification $\left(\mu \mathrm{g} . \mathrm{mL}^{-1}\right)$ & 0.17 & 0.11 \\
Correlation coefficient $(\mathrm{r})$ & 0.9999 & 0.9999 \\
Slope & $4.3 \times 10^{-3}$ & $4.5 \times 10^{-3}$ \\
Intercept & $-1.7 \times 10^{-4}$ & $1.0 \times 10^{-4}$ \\
Standard deviation of the residuals $\left(\mathrm{S}_{\mathrm{y} / \mathrm{x}}\right)$ & $7.6 \times 10^{-5}$ & $5.2 \times 10^{-5}$ \\
Standard deviation of the intercept $\left(\mathrm{S}_{\mathrm{a}}\right)$ & $7.3 \times 10^{-5}$ & $5.0 \times 10^{-5}$ \\
Standard deviation of the slope $\left(\mathrm{S}_{\mathrm{b})}\right.$ & $2.4 \times 10^{-6}$ & $1.7 \times 10^{-6}$ \\
Relative standard deviation $(\mathrm{RSD}, \%)$ & 0.46 & 0.53 \\
\% RSD/ $\sqrt{\mathrm{n}}$ (\% Error) & 0.19 & 0.21 \\
\multicolumn{2}{|l}{} \\
\hline
\end{tabular}

Linear regression analysis of the data gave the following equations:

$i_{d}=-1.7 \times 10^{-4}+4.3 \times 10^{-3} \mathrm{C} \quad(r=0.9999)$

using the $\mathrm{DC}_{\mathrm{t}}$ mode 
and

$i_{p}=1.0 \times 10^{-4}+4.5 \times 10^{-3} \mathrm{C} \quad(r=0.9999)$

using the DPP mode, respectively, where $C$ is the concentration in $\mu g \cdot \mathrm{mL}^{-1}, \mathrm{i}_{\mathrm{d}}$ is the diffusion current in $\mu \mathrm{A}$ in the $\mathrm{DC}_{t}$ mode and $\mathrm{i}_{\mathrm{p}}$ is the current in $\mu \mathrm{A}$ in the DPP mode.

\section{Method validation}

The proposed method was validated using the following criteria: linearity, sensitivity, intraday and interday precision, accuracy, robustness and selectivity.

Linearity

Linearity was evaluated by calculation of the regression equations over the ranges given in Table 3 .

The sensitivity of the method was evaluated by determining the limit of detection (LOD); according to ICH guidelines [23] LOD was defined as:

\section{$3.3 \times \delta / \mathrm{S}$}

where the standard deviation of the y-intercept of the regression lines $\delta$ (the standard deviation of the response) and $\mathrm{S}=$ the slope of the calibration curve.

The limit of detection (LOD) was found to be 0.06 and $0.04 \mu \mathrm{g} \cdot \mathrm{mL}^{-1}$ using the $\mathrm{DC}_{\mathrm{t}}$ and DPP modes, respectively.

The limit of quantification (LOQ) was also calculated according to ICH guidelines [23], and was found to be 0.17 and $0.11 \mu \mathrm{g} . \mathrm{mL}$ using the $\mathrm{DC}_{\mathrm{t}}$ and DPP modes, respectively, (Table 3). LOQ was calculated from the following equation:

$$
\mathrm{LOQ}=10 \delta / \mathrm{S}
$$

Statistical evaluation of the regression lines regarding standard deviation of the residual $\left(\mathrm{S}_{\mathrm{y} / \mathrm{x}}\right)$, standard deviation of the intercept $\left(\mathrm{S}_{\mathrm{a}}\right)$ and standard deviation of the slope $\left(S_{b}\right)$, is given in Table 3 . The small value of the figures points out to low scattering of the points around the calibration curve and high accuracy and high precision of the method [24].

\section{Precision}

Repeatability

The repeatability was performed through analysis of two concentrations of QTP in pure forms adopting the two polarographic modes (DPP and $\mathrm{DC}_{t}$ ) on three successive times, and the results are listed in Table 4.

Intermediate precision

It was performed through repeated analysis of QTP in pure form applying the proposed method, using the concentrations shown in Table 4, for a period of three successive days.

The repeatability and reproducibility in both modes were fairly good, as indicated by the small values of standard deviation (SD), relative standard deviation (RSD), and error (\% Er). 
Table 4. Validation of the proposed method for the determination of quetiapine in raw material.

\begin{tabular}{|c|c|c|c|c|c|}
\hline \multirow[b]{2}{*}{ Mode } & \multicolumn{2}{|c|}{ Intra-day precision } & \multicolumn{3}{|c|}{ Inter-day precision } \\
\hline & $\begin{array}{l}\text { \% Recovery } \\
16 \mu \mathrm{g} \cdot \mathrm{mL}^{-1}\end{array}$ & $\begin{array}{l}\text { \% Recovery } \\
24 \mu \text { g.mL }\end{array}$ & $\begin{array}{c}\text { Day } \\
\text { number }\end{array}$ & $\begin{array}{c}\% \text { Recovery } \\
16 \mu \text { g.mL }\end{array}$ & 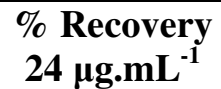 \\
\hline $1-\mathrm{DC}_{\mathrm{t}}$ mode & 99.02 & 99.60 & $1^{\mathrm{st}}$ & 99.02 & 99.60 \\
\hline & 99.73 & 100.39 & $2^{\text {nd }}$ & 100.87 & 99.35 \\
\hline & 100.66 & 100.27 & $3^{\text {rd }}$ & 100.44 & 101.19 \\
\hline $\begin{array}{l}\text { Mean found } \\
(\%) \pm S D\end{array}$ & $99.80 \pm 0.82$ & $100.09 \pm 0.43$ & & $100.11 \pm 0.97$ & $100.05 \pm 0.99$ \\
\hline RSD (\%) & 0.82 & 0.43 & & 0.97 & 0.99 \\
\hline$\%$ Error & 0.47 & 0.25 & & 0.56 & 0.57 \\
\hline 2 - DPP mode & 99.16 & 99.71 & $1^{\mathrm{st}}$ & 99.16 & 99.71 \\
\hline & 99.50 & 98.95 & $2^{\text {nd }}$ & 99.84 & 98.89 \\
\hline & 98.96 & 99.30 & $3^{\text {rd }}$ & 98.07 & 99.00 \\
\hline Mean found & $99.21 \pm 0.27$ & $99.32 \pm 0.38$ & & $99.02 \pm 0.89$ & $99.20 \pm 0.44$ \\
\hline $\operatorname{RSD}(\%)$ & 0.27 & 0.38 & & 0.89 & 0.44 \\
\hline$\%$ Error & 0.16 & 0.22 & & 0.51 & 0.25 \\
\hline
\end{tabular}

\section{Accuracy}

To test the validity of the proposed method, it was applied to the determination of authentic samples of QTP over the concentration range cited in Table 5. The results obtained were in good agreement with those obtained using a reference ultraviolet (UV spectrophotometric method) [2]. Using Student's t-test and variance ratio F-test, [24] revealed no significant difference between the performance of the two methods regarding accuracy and precision, respectively (Table 5).

\section{$\underline{\text { Robustness }}$}

The robustness of the method is demonstrated by the consistency of the diffusion current with minor changes in experimental variables that might reasonably be expected to take place during the course of the operation of the method, such as changing the molar concentration of the buffer over the range of $0.008-0.072 \mathrm{M}$ resulted in a negligible effect on the wave height of QTP.

\section{Interferences}

The proposed method is more specific and less liable to interference encountered from other co-administered drugs such as sertraline, citalopram, venlafaxine, mirtazapine and reboxetine, since they do not contain a susceptible reducible function group.

\section{Pharmaceutical applications}

Both $\mathrm{DC}_{\mathrm{t}}$ and DPP modes were successfully applied to the assay of QTP in its commercial tablets (seroquel). The percentage recoveries based on 4 separate determinations are 100.39 \pm 0.98 and 100.19 \pm 0.67 using $\mathrm{DC}_{\mathrm{t}}$ and DPP modes, 
respectively (Table 5). The results are in agreement with the label claim. The results obtained were statistically compared with those obtained using a conventional UV spectrophotometric method [2], where the absorbance of the methanolic solution was measured at $246 \mathrm{~nm}$. Statistical analysis of the results using the Student's t-test and the variance ratio F-test revealed no significant difference between the performance of the two methods regarding accuracy and precision, respectively (Table 5).

Table 5. Application of the proposed and reference methods to the determination of quetiapine in raw material and dosage form using $\mathrm{DC}_{t}$ and DPP modes.

\begin{tabular}{|c|c|c|c|c|}
\hline Sample & $\begin{array}{c}\text { Amount taken } \\
\left(\mu \mathrm{g} . \mathrm{mL}^{-1}\right)\end{array}$ & $\begin{array}{l}\text { Amount found } \\
\left(\mu \mathrm{g} \cdot \mathrm{mL}^{-1}\right)\end{array}$ & $\%$ recovery & $\begin{array}{l}\text { Reference method } \\
\text { \% Recovery }\end{array}$ \\
\hline $\begin{array}{c}\text { 1- Quetiapine raw } \\
\text { material using } \\
\mathrm{DC}_{\mathrm{t}} \text { mode } \\
\\
\text { Mean } \pm \mathrm{SD} \\
\text { Student t-test } \\
\text { F-value }\end{array}$ & $\begin{array}{c}8.0 \\
16.0 \\
24.0 \\
32.0 \\
40.0 \\
44.0\end{array}$ & $\begin{array}{c}7.95 \\
15.80 \\
23.76 \\
31.90 \\
35.57 \\
43.30\end{array}$ & $\begin{array}{c}99.38 \\
98.75 \\
99.00 \\
99.69 \\
98.93 \\
98.40 \\
99.03 \pm 0.46 \\
1.19(2.36) \\
5.61(5.79)\end{array}$ & $\begin{array}{l}99.12 \\
101.2 \\
99.56\end{array}$ \\
\hline $\begin{array}{c}2 \text { - Quetiapine raw } \\
\text { material using } \\
\text { DPP mode } \\
\\
\text { Mean } \pm \text { SD } \\
\text { Student t-test } \\
\text { (F-value) }\end{array}$ & $\begin{array}{l}8.00 \\
16.0 \\
24.0 \\
32.0 \\
40.0 \\
44.0\end{array}$ & $\begin{array}{c}7.98 \\
16.20 \\
24.20 \\
32.20 \\
40.42 \\
44.20\end{array}$ & $\begin{array}{c}99.75 \\
101.25 \\
100.83 \\
100.63 \\
101.05 \\
100.45 \\
100.66 \pm 0.53 \\
0.91(2.36) \\
4.25(5.79)\end{array}$ & $\begin{array}{l}99.12 \\
101.2 \\
99.56\end{array}$ \\
\hline $\begin{array}{c}\text { 3-Seroquel tablets } \\
\text { (quetiapine, } \\
300 \mathrm{mg} / \text { tablet) } \\
\text { using DPP mode } \\
\\
\text { Mean } \pm \text { SD } \\
\text { Student t-test } \\
\text { F value }\end{array}$ & $\begin{array}{l}16.0 \\
24.0 \\
32.0 \\
40.0\end{array}$ & $\begin{array}{l}15.88 \\
24.24 \\
32.40 \\
40.18\end{array}$ & $\begin{array}{c}99.25 \\
101.01 \\
101.25 \\
100.45 \\
\\
100.19 \pm 0.67 \\
0.57(2.57) \\
1.64(9.55)\end{array}$ & $\begin{array}{c}101.25 \\
99.60 \\
100.85\end{array}$ \\
\hline $\begin{array}{l}\text { 4-Seroquel tablets } \\
\text { (quetiapine, } \\
300 \mathrm{mg} / \text { tablet) } \\
\text { using } \mathrm{DC}_{\mathrm{t}} \text { mode } \\
\\
\text { Mean } \pm \mathrm{SD} \\
\text { Student t-test } \\
\text { (F-value) }\end{array}$ & $\begin{array}{l}16.0 \\
24.0 \\
32.0 \\
40.0\end{array}$ & $\begin{array}{l}16.01 \\
23.99 \\
32.59 \\
39.88\end{array}$ & $\begin{array}{c}100.05 \\
99.95 \\
101.84 \\
99.71 \\
\\
100.39 \pm 0.98 \\
0.27(2.57) \\
1.29(9.55)\end{array}$ & $\begin{array}{c}101.25 \\
99.60 \\
100.85 \\
\\
100.57 \pm 0.86\end{array}$ \\
\hline
\end{tabular}

Figures between parenthesis are the tabulated $t$ and $F$ values at $p=0.05$. 


\section{Selectivity}

The selectivity of the method was investigated by observing any interference encountered from the common excipients, such as talc, lactose, magnesium stearate, avisil and starch. These excipients did not interfere with the proposed methods.

\section{Conclusion}

A simple, rapid and sensitive method has been developed for the determination of QTP in formulations. The $\mathrm{DC}_{\mathrm{t}}$ and DPP modes could be successfully applied over the concentration ranges of $8-44 \mu \mathrm{g} \cdot \mathrm{mL}^{-1}$ and $4-44 \mu \mathrm{g} \cdot \mathrm{mL}^{-1}$ with lower detection limits of 0.06 and $0.04 \mu \mathrm{g} \cdot \mathrm{mL}^{-1}$ using $\mathrm{DC}_{t}$ and DPP modes, respectively, which are more applicable for dosage forms. The proposed method has distinct advantages over other existing methods regarding sensitivity, time saving and minimum detection limits and doesn't need highly sophisticated technique nor highly cost organic solvents which are required for HPLC technique.

\section{Acknowledgement}

F. Belal would like to thank the Alexander von Humboldt Foundation, Bonn, Germany, for kindly providing the instrument used in this study to his institute.

\section{References}

1. Engels Kleemann, "Encyclopedia of Pharmaceutical Substances", 4th ed., pdf, 2000.

2. V. Pucci, R. Mandrioli, A. Ferranti, S. Furlanetto, M. Augusta Raggi, J. Pharm. Biomed. Anal. 32 (2003) 1037-44.

3. E.U. Stolarczyk, A. Groman, Ł.S. Kaczmarek, P.Gołebiewski, Acta Pol. Pharm. 64 (2007) 187-189.

4. B. Barrett, M. Holcapek, J. Huclová, V. Borek-Dohalský, P. Fejt, B. Nemec, I. Jelínek, J. Pharm. Biomed. Anal. 44 (2007) 498-505.

5. Ch. Bharathi, K.J. Prabahar, Ch.S. Prasad, M. Srinivasa Rao, G.N. Trinadhachary, V.K. Handa, R. Dandala, A. Naidu, Pharmazie 63 (2008) 14-19.

6. H.B. Klinke, K. Linnet, Scand. J. Clin. Lab. Invest. 67 (2007) 778-782.

7. K.Y. Li, Y.G. Zhou, H.Y. Ren, F. Wang, B.K. Zhang, H.D. Li, J. Chromatogr. B. 850 (2007) 581-585.

8. L. Mercolini, M. Grillo, C. Bartoletti, G. Boncompagni, M.A. Raggi, Anal. Bioanal. Chem. 388 (2007) 235-243.

9. G. Migliardi, C. D'Arrigo, V. Santoro, A. Bruno, L. Cortese, D. Campolo, M. Cacciola, E. Spina, Clin. Neuropharmacol. 30 (2007) 107-113.

10. J. Rampono, J.H. Kristensen, K.F. Ilett, L.P. Hackett, R. Kohan, Ann. Pharmacother. 41 (2007) 711-714. 
11. R. Skibiński, Ł. Komsta, H. Hopkała, I. Suchodolska, Anal. Chim. Acta 590 (2007) 195-202.

12. H. Xu, D. Wang, C. Sun, Y. Pan, M. Zhou, J. Pharm. Biomed. Anal. 44 (2007) 414-420.

13. F. Belal, A. El-brashy, M. Eid, J.J. Naser, J. Liq. Chromatogr. Relat. Technol. 31 (2008) 1283-1298.

14. G. Garrido, C. Ràfols, E. Bosch, Eur. J. Pharm. Sci. 28 (2006) 118-127.

15. S. Hillaert, L. Snoeck, W. Van den Bossche, J. Chromatogr. A 1033 (2004) 357-362.

16. J. Heyrovsky, P. Zuman, in "Practical Polarography", London, UK, Academic Press, 1968.

17. H. Oelschlager, J. Volke, F. Belal, Arch. Pharm. 325 (1992) 65-68.

18. A.C. Moffat, M.D. Osselton, B. Widdop, L.Y. Galichet, Editors in "Clark's Analysis of Drugs and Poisons in Pharmaceuticals, Body Fluids and Post Mortem Materials", $3^{\text {rd }}$ Ed., The Pharmaceutical Press, Vol. II, London (2004) p.1053.

19. J. Proszt, V. Cieleszky, K. Gyorbiro, in "Polarography", Akademiai Kiado, Budapest, Hungary, 1967.

20. L. Meites, Y. Israel, J. Am. Chem. Soc. 83 (1961) 4903-4906.

21. J. Heyrovsky, J. Kuta, in "Principles of Polarography", Prague, Czechoslovak Academy of Science, 1965.

22. N.M. El-Enany, S. Al-Ghanam, and F. Belal, J. Pharm. Ind. 65 (2003) 7681.

23. Guidance for Industry; Q2B of Analytical Procedures: Methodology; International Conference on Hormonization (ICH), November 1996. http://www.fda.gov/eder/guidance/1320fnl.pdf (accessed September 1, 2004).

24. J.N. Miller, J.C. Miller, "Statistics and Chemometrics for Analytical Chemistry", 5th ed., England: Prentice Hall. 2005, p.256. 